\title{
Inspire the Leadership Potential: Leadership Promotion of Chinese Women under the Background of Social Gender Mainstreaming
}

\author{
Lianfang Zhang \\ Faculty of Public Administration, Jinan University, Guangzhou, China \\ Email: zlfldne@qq.com
}

How to cite this paper: Zhang, L.F. (2017) Inspire the Leadership Potential: Leadership Promotion of Chinese Women under the Background of Social Gender Mainstreaming. American Journal of Industrial and Business Management, 7, 360-371. https://doi.org/10.4236/ajibm.2017.74026

Received: February 16, 2017

Accepted: April 15, 2017

Published: April 18, 2017

Copyright $\odot 2017$ by author and Scientific Research Publishing Inc. This work is licensed under the Creative Commons Attribution International License (CC BY 4.0).

http://creativecommons.org/licenses/by/4.0/

\begin{abstract}
Looking at the political practice of women in the world, today with the constant development of the feminist movement and the feminist consciousness, women participate in competitive election and parliamentary vote, and make decisions in policies like men. They manage state affairs and share political tasks with men. The female leadership is gradually emerging. However, during the efforts under the background from the social gender perspective, in the process of their growth and development Chinese female leaders have their special difficulties, which shall be solved and improved, in order to inspire the advantages of women in leadership and allow them to manage the society more effectively.
\end{abstract}

\section{Keywords}

Leadership, Feminist Movement, Political Participation

\section{The Premise and Support-Feminist Movement from the Perspective of Social Gender}

Marx once commented on Chinese women: "Everyone who knows anything of history also knows that great social revolutions are impossible without the feminine ferment. Social progress may be measured precisely by the social position of the fair sex." [1]. For the development of human political civilization or the construction of social integrity, modern politics without the participation of women are deformed and incomplete politics. Since the 1820s, due to the urbanization process and the change of social relationship brought by the industrial revolution, more women have participated in social productive labor. Seen from the development history of feminist movement, women's appeal of equality between 
both sexes is no longer just limited to the independence of economy and the marriage equality. Women began to demand for higher social status and political identity, and their political participation also became increasingly active. "Without the full participation and the full power of women all over the world, the most threatening social, economic and political problems of the human society will not be able to be solved permanently". The UN Fourth World Conference on Women commented on the female movement lasting for a century. The world reached a new consensus. Women can also participate in politics, and the practical significance is extraordinary. Since then, women's participation in politics reached a new stage. The social gender consciousness mainstreaming has become the global strategy of gender equality, which provides a new path for the political participation of women.

\subsection{The Feminist Movements Are in the Ascendant}

In the $14^{\text {th }}$ century at the beginning of the Renaissance, with the call of the times of tracing back to the light of reason and highlighting people-oriented, the feminist consciousness gradually began to spread on the continent of Europe. Until the $17^{\text {th }}$ century, the enlightenment era with the theme of natural rights and "all men are created equal" started women's revitalization. Since then women's actions of maintaining their own rights really began. After the baptism of bourgeois revolution, the concept of "liberty, equality and philanthropism" enjoyed popular support. Feminism Proclamation, the first declaration of women's rights showing the complete feminist thought in human history, appeared. Since the second half of the eighteenth century, "the main line of action was the fight for rights, and the main line of theory was reflection and criticism of the traditional mainstream theories" [2]. There were a series of women's liberation movements with the belief consciousness of "equality between men and women". The first wave of feminist movements demanded the equality of labor rights, the second wave of feminist movements strived for equality of political and legal status of both sexes, and the third wave tried to break from the patriarchal environment and was committed to explore gender differences and diversity. So far the feminist movements never stopped. At the same time, different theoretical schools appeared in the academic circle, including liberal feminism, radical feminism, modern socialist feminism and postmodern feminism, which analyzed women's effect and significance for political civilization from different historical background and characteristics of different stages. Women's fight for their rights always affects the process of human development.

The rise of the feminist consciousness is the enlightenment and premise of women's participation in politics. Women's movement is the strong support of women's participation in politics. Such self awakening from the western democratic liberalism spirit containing the sense of equity from the humanism not only provides possibility for women's rejudgment of self being and self values, but also is the necessary way for the nation and the state to realize citizens' political rights and promote the democratic process, and the important basis for 
women with potential to be effectively involved in the public affairs and management.

\subsection{Efforts from the Perspective of Social Gender}

The social gender theory continuously gives the new realistic explanation significance to women's participation in politics in academic theory. As an analysis tool, it rejects the idea of binary opposition, advocates and encourages multiple coexistence, and advocates treating different genders in a just and equal manner in gender difference. Thus, feminism maintainers and advocates gradually changed their consciousness, and improved from the will neglecting gender differences and striving for "absolute equality between men and women" to the pursuit of "shared governance of both sexes". The goal of women's participation in politics is not just to change the existing social status of woman, but also to realize the harmonious shared governance of both sexes in the process of the pursuit of gender equity" [3]. Thus, Gender Mainstreaming advocated by the United Nations has become the new strategy of gender equality in the world. In the decision making process of different countries in the world, such a national responsibility is gradually formed. The new trend focuses on weighing the equal benefits of both sexes, uses the method of promoting social fairness and justice, and aims at eliminating the social sex discrimination.

The concept of social gender was originated from the second wave of women's movements in the 1960s, and proposed by American anthropologist Gail Rubin for the first time. Different from biological sex, social gender is standardized and constrained by social culture, and can change along with the social change. Some scholars summarize it as "the behavioral pattern and group characteristics of men or women formed in the social culture" [4]. Although the relevant social gender theory is controversial, it reflects a kind of practical trend. In the male-dominated gender politics and the western dualism ideology, the change of subordinate and service role of women needs the premise of the change of the whole mainstream culture. As Anders Johansson, Secretary General of Inter-parliamentary Union, said, women could bring a lot of things different from men to politics, such as social consciousness, and could deal with and resolve conflicts in their own way. On the one hand, women can use their gender characteristics and advantages when they participate in politics, and bring the unique scenery line different from traditional power politics from the perspective of men; on the other hand, women's participation in politics also has profound social significance. It can realize social harmony and social justice brought by the expectation of social gender equality.

\section{Opportunities and Challenges-International Practice of Women's Participation in Politics}

\subsection{Women's Political Opportunities for Themselves}

In 1869 American feminists proposed "women's will of participation in politics". At the beginning of the $20^{\text {th }}$ century, the western feminist movement and the li- 
beralism thought of "equality of men and women" constantly influenced countries and areas all over the world. Women from different countries also gradually participated in the political field. Women's participation in politics has a lot of modern significance and connotation. "It refers to activities in which the female citizens try to influence and promote the decision-making process of the political system." [5]. It means that women enter the organs of authority, serve as leaders and managers and exercise certain political and management powers. Some scholars also defined as "including knowing, discussing about, participating in politics and being in power. Knowing and discussing about politics is the foundation of women's participation in politics, and a sign of awareness of political participation; participating in politics and being in power refer to the specific activities of women's participation in politics, and the expression of the political participation behavior." [3].

Since human civilization entered the modern times, women were anxious for slipping the leash of the patriarchal traditional role and realizing their own right claims and protection. Women's realization of political participation is not just enjoying the right to vote, the right to be voted and other rights of democratic participation at the basic level. Women's desire to realize their own rights changed to demand for political power and the right to participate in and to discuss about political affairs. Outstanding women active in politics often have positive power participation. From the former British Prime Minister Margaret Thatcher to South Korea's President Park Geun-hye, the first female President elected by people in East Asia, German Chancellor Angela Merkel known as the "iron lady" of the new era, and Hilary Clinton, the former Secretary of State of the United States, who has been active in the female political vision of the world, in the political circle around the world there is no lack of good and outstanding female leaders and politicians. In different regional culture background they have different leader spirit and energy. Although they have roughly similar politics experience, they have different courage of leaders. Due to such charm and courage, these outstanding women play important roles in the countries all over the world (See Table 1).

Seen from statistical data of positions of the world's female leaders, more and more women hold important positions in the field such as national safety and security, finance and diplomatic relations. Women's scope of powers expanded in the participation in political areas such as education and health. Due to women's full participation at the power level, "women often play the auxiliary role of promotion or fund raising, and few of them reached a higher level in the party." [6]. The traditional role model of "qualified women" was broken. At the same time, it is also beneficial to the improvement of women's enthusiasm in participation in politics. This phenomenon is associated with the economic and cultural development of different countries. These women are able to become leaders mainly because of controllable resources of these women as individuals and non-gender factors. The active and optimistic mood and being good at learning and communication are the necessary premises for the growth of these 
Table 1. Statistics of assumption of duty by the world's main female national leaders in recent years.

\begin{tabular}{llll}
\hline Date of assumption & \multicolumn{1}{c}{ Position } & \multicolumn{1}{c}{ Name } & \multicolumn{1}{c}{ Country } \\
\hline November $22^{\text {nd }}, 2005$ & Prime Minister & Angela Merkel & Germany \\
January $16^{\text {th }}, 2006$ & President & Ellen Johnson-Sirleaf & Liberia \\
December $10^{\text {th }}, 2007$ & President & Cristina Fernández de Kirchner & Argentina \\
July $12^{\text {th }}, 2009$ & President & Dalia Grybauskaite & Lithuania \\
January $1^{\text {st }}, 2011$ & President & Dilma Rousseff & Brazil \\
October $3^{\text {rd }}, 2011$ & Prime Minister & Helle Thorning-Schmidt & Denmark \\
February $25^{\text {th }}, 2013$ & President & Park Geun-Hye & South Korea \\
January $20^{\text {th }}, 2014$ & President & Catherine Samba-Panza & Central African Republic \\
March $11^{\text {th }}, 2014$ & President & Michelle Bachelet & Republic of Chile \\
September $22^{\text {nd }}, 2014$ & Prime Minister & Ewa Kopacz & Poland \\
November $19^{\text {th }}, 2014$ & First Minister & Nicola Sturgeon & Scotland \\
February $18^{\text {th }}, 2015$ & President & Kolinda Grabar-Kitarović & Croatia \\
\hline
\end{tabular}

Source: Wikipedia (https://en.wikipedia.org).

female leaders; good knowledge accomplishment and personality charm are superior resources for these women to show their leadership; and they can coordinate or handle the relationship among marriage, family and career. At the same time, studies have shown that "young women clearly appreciate female politicians, which means the female politicians are examples and models of the young women, so they are likely to promote women to participate in politics." [7]. These female leaders' political career and performance in the process of role performance will resonate women who expect the same experience, thus raising such women's political consciousness and arousing their enthusiasm of participation in politics.

\subsection{The Challenges of International Women's Participation in Politics}

However, there are some unavoidable realistic challenges in the growing political participation of international women. In the process of international women's participation in politics, apart from the challenges of the existing financial and material limitations, cultural differences and traditional concepts are also the biggest challenges of women's leadership career. In this study, the following two typical challenges are the main findings.

The first challenge is the imbalance in the context of differentiation. There are different kinds of consciousness demands in different regions of the world, so international women still cannot avoid the imbalance caused by regional differences in the process of political participation. The highest proportion of women in the world's participation in politics includes Northern Europe and South Asia, 
while women in other places have less participation in politics. There are two main reasons: the first reason is that the concept of gender equality has lodged itself in the public mind, women there are highly educated and their political achievements are very outstanding; the other reason is due to the hereditary system and inheritance. It can be seen that women are subject to resource differences, especially cultural differences caused by economic differences. Therefore, how to realize the sharing of consciousness in differences is an important challenge to women's leadership.

The second challenge is the female role conflict in the traditional concept. In the traditional concept, women are still positioned as auxiliary roles for men, and women cannot set foot in the high-level political areas to control the right. Although the international women's rights protection organizations provide help, it is far from trivial for the deeply rooted ideas. In the practice of international women's participation in politics, it can be found everywhere that female leaders' career advancements are obstructed by the suppression of the high-level male domination. The former Secretary of State of the United States Hillary Clinton also mentioned in her speech to the public after the election failed, "I know we have still not shattered that highest and hardest glass ceiling." It can be seen that the deep-seated feminine status of the traditional concept of women is another challenge to political practice of women.

\section{Dilemma and Future-Inspiration of the Leadership Potential of Chinese Women}

Today social gender mainstreaming is advocated. Looking at the growth and development process of the international female leaders, those outstanding female leaders not only benefit from external support in the objective environment. Their individual charm also shows the quality and potential of leaders, which shall be studied and referred to by Chinese female leaders.

\subsection{Basic Conditions of Women's Participation in Politics and the Development of Female Leaders in China}

In 1954, Constitution of the People's Republic of China explicitly stipulated that women shall enjoy equal rights with men in politics, economy, culture, social and family life and other aspects. Since then Chinese women's political power was further improved. The proportion of women in the National People's Congress in 1954 changed from $12 \%$ in 1954 to $23.4 \%$ in 2013 . There is a trend of increase year by year (The data comes from China Statistical Yearbook Network). In 2013 the $18^{\text {th }}$ Congress incorporated equality between men and women as a basic national policy into the report for the first time. This will not only guarantee interests in all aspects and improve the social status of Chinese women, but also have far-reaching significance for Chinese women's participation in politics as a national strategy with the concept of scientific development. However, since the reform and opening up under the impetus of market economy, in China both men and women are more equal in political participation, but the 
proportion of women at the decision-making levels is low. We can see it from the proportion of women in the central committee members since the reform and opening up (See Table 2).

Outstanding female leaders emerged in large numbers in the political field in China. The author analyzed the list and resumes of female leaders in leaders of the municipal party committees and governments of provinces and municipalities, and main leaders of the party and the government of Municipal People's Congress Standing Committee, Municipal Political Consultative Conference and municipal districts under each province. As of March 2016, there are 128 female leaders among municipal/district party committees, government leaders, directors and deputy directors of National People's Congress, and Chairmen and Vice Chairmen of Municipal Political Consultative Conference in different districts and cities in the provinces and autonomous regions (not including Hong Kong, Macao and Taiwan regions), accounting for $11 \%$ of the total number (See Table 3). Seen from the position setting, they mainly work in administrative organs, and hold the deputy posts of democratic and political consultation. Their main jurisdiction area is science-education-culture-health; seen from the hierarchical structure, there are few middle-and-high-level female leaders. There is the phenomenon of "pyramid". There are few high-level female leaders. Although the "duty gender" phenomenon still exists, female leaders have gradually become the important performance in the period of social transformation in China, and the appointment and selection of female cadres constantly develop and change.

\subsection{The Main Reasons Restricting the Inspiration of Leadership of Women in China}

The main reasons restricting the inspiration of leadership of women include the objective environment and subjective factors.

Table 2. The proportion of women in the central committee members (since the reform and opening up).

\begin{tabular}{lcc}
\hline & $\begin{array}{c}\text { The number of women/Total number } \\
\text { of the central committee members }\end{array}$ & $\begin{array}{c}\text { The proportion } \\
\text { of women }\end{array}$ \\
\hline The $11^{\text {th }}$ Central Committee & $14 / 201$ & $7.0 \%$ \\
The $12^{\text {th }}$ Central Committee & $11 / 210$ & $5.2 \%$ \\
The $13^{\text {th }}$ Central Committee & $9 / 175$ & $5.1 \%$ \\
The $14^{\text {th }}$ Central Committee & $12 / 193$ & $6.2 \%$ \\
The $15^{\text {th }}$ Central Committee & $8 / 193$ & $4.2 \%$ \\
The $16^{\text {th }}$ Central Committee & $5 / 197$ & $2.5 \%$ \\
The $17^{\text {th }}$ Central Committee & $13 / 204$ & $6.4 \%$ \\
The $18^{\text {th }}$ Central Committee & $10 / 205$ & $4.9 \%$ \\
\hline
\end{tabular}

(Source: News Network of the Communist Party of China: http://cpc.people.com.cn/GB/64162/139962/index.html). 
Table 3. The number of middle-and-high-level female leaders in China (by March 2016).

\begin{tabular}{|c|c|c|c|c|c|}
\hline Province or city & $\begin{array}{c}\text { Total } \\
\text { number }\end{array}$ & Female & $\begin{array}{l}\text { The number of women/Total } \\
\text { number (leaders of the } \\
\text { municipal party committee } \\
\text { and government) }\end{array}$ & $\begin{array}{c}\text { The number of women/Total } \\
\text { number (directors and deputy } \\
\text { directors of municipal people's } \\
\text { congress) }\end{array}$ & $\begin{array}{c}\text { The number of women/Total } \\
\text { number (Chairman and Deputy } \\
\text { Chairman of Municipal Political } \\
\text { Consultative Conference) }\end{array}$ \\
\hline Beijing & 37 & 4 & $1 / 18$ & $1 / 8$ & $2 / 11$ \\
\hline Tianjin & 40 & 5 & $2 / 20$ & $1 / 9$ & $2 / 12$ \\
\hline Hebei Province & 37 & 3 & $1 / 16$ & $1 / 11$ & $1 / 11$ \\
\hline Shanxi Province & 33 & 4 & $2 / 18$ & $1 / 8$ & $1 / 8$ \\
\hline Inner Mongolia & 38 & 3 & $2 / 20$ & $0 / 8$ & $1 / 11$ \\
\hline Liaoning Province & 37 & 3 & $1 / 19$ & $1 / 10$ & $1 / 10$ \\
\hline Jilin Province & 33 & 3 & $0 / 16$ & $2 / 8$ & $1 / 10$ \\
\hline Heilongjiang & 38 & 5 & $1 / 19$ & $2 / 9$ & $2 / 10$ \\
\hline Shanghai & 37 & 6 & $2 / 18$ & $2 / 8$ & $2 / 11$ \\
\hline Jiangsu Province & 35 & 4 & $4 / 15$ & $0 / 10$ & $1 / 13$ \\
\hline Zhejiang Province & 39 & 6 & $2 / 19$ & $2 / 11$ & $2 / 13$ \\
\hline Anhui Province & 38 & 3 & $1 / 17$ & $2 / 11$ & $0 / 11$ \\
\hline Fujian Province & 42 & 4 & $2 / 19$ & $2 / 12$ & $0 / 13$ \\
\hline Jiangxi Province & 37 & 5 & $2 / 21$ & $2 / 8$ & $1 / 10$ \\
\hline Shandong Province & 37 & 5 & $2 / 21$ & $1 / 8$ & $2 / 9$ \\
\hline Henan Province & 41 & 4 & $3 / 24$ & $0 / 8$ & $1 / 11$ \\
\hline Hubei Province & 36 & 4 & $1 / 19$ & $2 / 9$ & $1 / 9$ \\
\hline Hunan Province & 37 & 3 & $2 / 19$ & $1 / 11$ & $1 / 9$ \\
\hline Guangxi Province & 37 & 5 & $2 / 20$ & $1 / 8$ & $2 / 12$ \\
\hline Hainan Province & 35 & 4 & $2 / 17$ & $1 / 8$ & $1 / 11$ \\
\hline Chongqing Province & 39 & 5 & $3 / 21$ & $1 / 8$ & $1 / 11$ \\
\hline Sichuan Province & 42 & 3 & $1 / 21$ & $1 / 10$ & $1 / 12$ \\
\hline Guizhou Province & 37 & 2 & $1 / 19$ & $0 / 7$ & $1 / 12$ \\
\hline Xinjiang & 48 & 4 & $1 / 24$ & $1 / 9$ & $2 / 15$ \\
\hline Ningxia & 38 & 5 & $1 / 9$ & $1 / 10$ & $3 / 11$ \\
\hline Shaanxi Province & 38 & 7 & $2 / 19$ & $2 / 9$ & $3 / 11$ \\
\hline Gansu Province & 38 & 4 & $2 / 20$ & $1 / 8$ & $1 / 11$ \\
\hline Qinghai Province & 39 & 4 & $1 / 19$ & $2 / 9$ & $1 / 12$ \\
\hline Tibet & 40 & 3 & $0 / 14$ & $1 / 12$ & $2 / 14$ \\
\hline Yunan Province & 41 & 4 & $1 / 23$ & $2 / 8$ & $1 / 11$ \\
\hline Guangdong Province & 38 & 4 & $1 / 19$ & $2 / 9$ & $1 / 10$ \\
\hline Total number & 1182 & 128 & & & \\
\hline
\end{tabular}

(Source: China Economy Network http://district.ce.cn/zt/rwk/sf/bj/index.shtml). 
First, the deeply rooted traditional gender idea environment still exists, which hinders the role definition of female leaders from the body and mind in their growth. According to traditional ideas, women are not as strong as women, have richer emotional feelings than men, and are naturally vulnerable. If they cannot control empathy and sympathy well, their work will be influenced by emotional factors and they may act impetuously. Due to these psychological and emotional factors, female leaders and cadres are limited in their growth.

Second, the promotion and safeguard environment of the personnel selection mechanism and the legal mechanism needs to be improved. Under the same conditions, female cadres cannot be treated in a relatively just and fair manner. The national or local regulations on political participation or right representative of women are not clear. There is also a lack of corresponding guarantee on the system. For example, in terms of the proportion of men and women, it is expressly stipulated in the policy that "at least one woman" means that there are few or only one female cadre. At the same time, in the process of selection and promotion, women often cannot get the selection and training opportunities due to their gender identity. Female superiors may exert a certain pressure on promotion and selection of female cadres. Female cadres may also be stifled by male superiors to avoid arousing suspicion. The lack of relevant legal protection is also the main obstacle of female leaders in the process of growth for selection and training. For example, in the working process when they encounter problems and disputes or discrimination, because the related legal system is not sound, the female leaders and cadres cannot find the corresponding right protection department for relief and responsibility investigation.

Finally, due to family factors it is difficult for female leaders to coordinate work and family, so marriage and career of most of the female leaders and cadres are relatively not harmonious. This is because female leaders and cadres' care of marriage and family is more than career advancement and the commitment to work tasks. Due to this phenomenon, some female leaders and cadres' political participation is not enough, they are not anxious for career promotion, and they lack certain courage and execution force of leadership; due to special physiological conditions, especially the child-bearing and lactation period, relative to men women lack consistency of overall arrangement or leadership tasks, and they have less time and energy than men with the same age and identity. Due to the concept of weak body and mind of women, female leaders lack independent consciousness and competitive consciousness in the selection or promotion, so that some female leaders and cadres call themselves vulnerable groups and content with the current situation;

\subsection{Inspiration of Potential of Chinese Leaders under the Enlightenment from Female Leaders in the World}

The growth and development of female cadres cannot go without the efficient utilization of policy, capital and other resources, and the consciousness of self awareness. How to play a role in the gender difference, grow, serve as a good 
leader and maximize the benefit of leadership is the challenge faced by outstanding female leaders in the future development.

First, for the development, female leaders and cadres need to make full use of the favorable political environment such as policies, regulations and legal protection. Female leaders and cadres have advantage resources of policies, including some policy advantages, such as political participation opportunities in the rational rules of the political system in the general election system. For example, according to the Opinions on Doing a Good Job in Cultivating and Selecting Female Cadres and Developing Female Party Member, the leading group of provincial party committee, National People's Congress and the Chinese People's Political Consultative Conference, and the county-level party committee and government shall have 1 female cadre each. For the central government, state organs, ministries and commissions, provinces, autonomous regions, municipalities directly under the central government and the municipal party committees and government departments, the leading group shall have more than half of female cadres. And then in 2002, the central government held the working conference for cultivating and selecting female cadres again, so that Chinese women's political status was dramatically improved.

Second, making full use of the special gender resources is an important advantage resource in the growth and development of female cadres. Women can share others' empathy psychologically and behaviorally, help them to motivate and encourage or make them have the cohesion based on emotional community. Compared to men, women have the appeal and charm of maternal care; at the same time, they have the experience thinking of learning and summarizing of experience and the image thinking of reflecting and grasping the direct image, which can help female leaders and cadres to draw inferences about other cases from one instance in the process of problem solving and improve their problem analysis and solving ability. At the same time, the decision objective abstraction of leaders also helps to make the unconventional relevant decision, which is female leaders and cadres' gender advantage compared to male leaders. So women get additional resources in the process of political participation, thus improving their political ability and execution level, and accumulating enough political knowledge, experience and qualifications, so that in the operation and management subordinates and people tend to be more convincing with authority and complying with the task. Therefore, female leaders must be good at using their advantages to analyze available resources, actively cultivate innovative thinking ability and enhance the political sensitivity in work, improve self-cultivation and quality in life, and show the beauty of women's leadership with hardness and softness, so as to create the charming personality.

Finally, for the growth and development of female leaders and cadres, the favorable economic and political environment needs to be created. Joining a political party organization, establishing a power maintenance system and establishing the good and effective social capital is the necessary premise of improving women's political participation and promoting the development and playing of 
leadership. An important feature of contemporary politics is party politics. The personal power shall depend on the party's political power to grow, draw attention and maintain the corresponding leadership rights and interests. By attending a party or a political organization, female leaders and cadres practice and improve in the organization, strive for the leader status in the organization like male cadres, set up the prestige and reputation in the process, and build a solid maintaining system, so as to consolidate and strengthen the leading foundation. At the same time, the necessary social resource is another factor for the success of female leaders. Dealing with the balance between marriage and family and job promotion can be regarded as an important social capital of female leaders. This is an important factor which determines whether female leaders can have smooth promotion and development. In addition, actively joining the social circle of different classes and building a relationship with the power group is one of the social capital for women to take advantages. Libby Sartain, the former President of Society for Human Resource Management (SHRM), said: "Establishing a good relationship with groups higher than, equal to or lower than you is the key to success". [8]. So in addition to the strength and ability of female leaders, the effective capital and resources inside and outside the organization is also an indispensable element for the growth and development of female leaders.

In a word, the deepening of the global women's movement and the liberal democratic thought influenced different countries and regions. At the same time, the process of political decision democratization also realized the power and democratic participation in politics of today's women. More outstanding women will be engaged in politics. The history of the development of human society changed from being controlled and dominated by a few people gradually to participation in decision making and sharing of rights by most of the people [9]. Taking gender advantages has become the future development trend of leadership. Female leaders need to continuously regenerate and grow in this trend, and inspire their own leadership potential, so as to realize their values and give full play to the gender advantages, so as to cooperate with men together and work out a good blueprint.

\section{References}

[1] Marx, Engels, Lenin and Stalin (2012) Selected Works of Marx and Engels. Works Compilation \& Translation Bureau of the Central Committee of the Communist Party of China, Vol. 4, People's Publishing House, Beijing, 480.

[2] Tong, X. (2005) Introduction to Studies on Social Gender: Analysis on the Unequal Social Mechanism of Both Genders. Peking University Press, Beijing, 222.

[3] Bao, J. (2013) Women's Participation in Politics: Question about Social Gender. China Renmin University Press, Beijing, 200, 52.

[4] Li, C.T. (2003) International Politics from the Perspective of Social Gender. Shanghai People's Publishing House, Shanghai, 18.

[5] Shi, F.L. (2011) Study on the Participation in Politics by Contemporary Women. Shandong University Press, Jinan, 39.

[6] Kathleen Newland (1975) Women in Politics: A Global Review. Worldwatch Paper, 


\section{3,22 .}

[7] Elder, L. (2004) Why Women Don't Run: Explaining Women's Underrepresentation in America's Political Institutions. Women \& Politics, 26, 43-45.

[8] Friedman, C. and Yorio, K. (2007) The Girl's Guide to Being a Boss (without Being a Bitch): Valuable Lessons, Smart Suggestions, and True Stories for Succeeding as the Chick-in-Charge. Morgan Road Books, New York.

[9] Wang, J.L., Ed. (2006) Women Development Blue Book-China Women Development Report No. 1 (95+10). Social Sciences Academic Press, Beijing, 241.

Submit or recommend next manuscript to SCIRP and we will provide best service for you:

Accepting pre-submission inquiries through Email, Facebook, LinkedIn, Twitter, etc. A wide selection of journals (inclusive of 9 subjects, more than 200 journals)

Providing 24-hour high-quality service

User-friendly online submission system

Fair and swift peer-review system

Efficient typesetting and proofreading procedure

Display of the result of downloads and visits, as well as the number of cited articles Maximum dissemination of your research work

Submit your manuscript at: http://papersubmission.scirp.org/

Or contact ajibm@scirp.org 